\title{
Corrigendum: In the Wrong Place at the Wrong Time: Identifying Spatiotemporal Co-occurrence of Bycaught Common Dolphins and Fisheries in the Bay of Biscay (NE Atlantic) From 2010 to 2019
}

Helene Peltier ${ }^{1,2 *}$, Matthieu Authier ${ }^{1,2}$, Florence Caurant ${ }^{1,3}$, Willy Dabin ${ }^{1}$, Pierre Daniel ${ }^{4}$, Cecile Dars ${ }^{1,2}$, Fabien Demaret ${ }^{1,2}$, Eleonore Meheust ${ }^{1}$, Olivier Van Canneyt ${ }^{1}$, Jerome Spitz ${ }^{1,3}$ and Vincent Ridoux ${ }^{1,3}$

${ }^{1}$ Observatoire Pelagis, UMS 3462-Université de La Rochelle-CNRS, La Rochelle, France, ${ }^{2}$ ADERA, Pessac, France, ${ }^{3}$ Centre d'Études Biologiques de Chizé-La Rochelle, UMR 7372-Université de La Rochelle-CNRS, La Rochelle, France,

${ }^{4}$ Météo-France, DirOP/MAR, Toulouse, France

Keywords: bycatch, fishing effort, strandings, reverse drift, Bay of Biscay, VMS data

OPEN ACCESS

Edited and reviewed by: Jeremy Kiszka

Florida International University, United States

*Correspondence: Helene Peltier hpeltier@univ-Ir.fr

Specialty section: This article was submitted to Marine Megafauna,

a section of the journal Frontiers in Marine Science

Received: 01 May 2021 Accepted: 05 May 2021 Published: 26 May 2021

Citation:

Peltier $\mathrm{H}$, Authier $M$, Caurant $F$ Dabin W, Daniel P, Dars C, Demaret F, Meheust E, Van Canneyt O, Spitz and Ridoux V (2021) Corrigendum: In the Wrong Place at the Wrong Time: Identifying Spatiotemporal

Co-occurrence of Bycaught Common Dolphins and Fisheries in the Bay of Biscay (NE Atlantic) From 2010 to 2019. Front. Mar. Sci. 8:704005. doi: 10.3389/fmars.2021.704005

\section{A Corrigendum on}

In the Wrong Place at the Wrong Time: Identifying Spatiotemporal Co-occurrence of Bycaught Common Dolphins and Fisheries in the Bay of Biscay (NE Atlantic) From 2010 to 2019 by Peltier, H., Authier, M., Caurant, F., Dabin, W., Daniel, P., Dars, C., et al. (2021). Front. Mar. Sci. 8:617342. doi: 10.3389/fmars.2021.617342

In the original article, there was an error. The text originally stated that "Between 5,000 and 10,000 strandings of bycaught common dolphins were recorded along the French Atlantic coast each year from 2016 to 2018 (ICES, 2020b; Peltier et al., 2020)."

A correction has been made to Introduction, paragraph five:

"Between 5,000 and 10,000 bycaught common dolphins were estimated in French Atlantic waters each year from 2016 to 2018 (ICES, 2020b; Peltier et al., 2020)."

The authors apologize for this error and state that this does not change the scientific conclusions of the article in any way. The original article has been updated.

\section{REFERENCES}

ICES (2020b). Workshop on fisheries Emergency Measures to minimize BYCatch of short-beaked common dolphins in the Bay of Biscay and harbour porpoise in the Baltic Sea (WKEMBYC) [Draft Report]. (ICES Scientific Reports). Vol. 2. Copenhagen: ICES.

Peltier, H., Authier, M., Dabin, W., Dars, C., Demaret, F., Doremus, G., et al. (2020). Can modelling the drift of bycaught dolphin stranded carcasses help identify involved fisheries? An exploratory study. Glob. Ecol. Conserv. 21:e00843. doi: 10.1016/j.gecco.2019.e00843

Copyright ( 2021 Peltier, Authier, Caurant, Dabin, Daniel, Dars, Demaret, Meheust, Van Canneyt, Spitz and Ridoux. This is an open-access article distributed under the terms of the Creative Commons Attribution License (CC BY). The use, distribution or reproduction in other forums is permitted, provided the original author(s) and the copyright owner(s) are credited and that the original publication in this journal is cited, in accordance with accepted academic practice. No use, distribution or reproduction is permitted which does not comply with these terms. 